\title{
Does Technological Pedagogical Content Knowledge Impact on the Use of ICT in Pedagogy?
}

\author{
https://doi.org/10.3991/ijet.v15i03.11690 \\ Hanna Andyani ( $\left.{ }^{\varpi}\right)$, Punaji Setyosari, Bambang Budi Wiyono, \\ Ery Tri Djatmika \\ Universitas Negeri Malang, Malang, Indonesia \\ hannaandyani@gmail.com
}

\begin{abstract}
The development of information and communication technology (ICT) has led to opportunities and challenges in the educational ideas and practices. This study examines the impact of technological pedagogical content knowledge on the use of ICT in pedagogy. This study applied a quantitative method using Structural Equation Model (SEM). The population of the study was teacher in Junior high School in Mojokerto of East Java Indonesia while the sample was about 308 participants gathered by using proportionate stratified random sampling. The findings showed that first, technological pedagogical content knowledge directly did not affect teachers' self-efficacy. Second, technological pedagogical content knowledge influences the use of ICT in pedagogy. Third, organizational innovative climate directly influences the teachers' self-efficacy. Indeed, organizational innovative climate affects the use of ICT in pedagogy. Fifth, teachers' self-efficacy influences the use of ICT in pedagogy. Sixth, technological pedagogical content knowledge mediated by teachers' self-efficacy does not directly affect the use of ICT in pedagogy. Lastly, organizational innovative climate-mediated by teachers' self-efficacy affects the use of ICT in pedagogy. This research could be the first step for a similar study in the future.
\end{abstract}

Keywords - Technological Pedagogical Content Knowledge, Organizational Innovative Climate, Teachers' Self-Efficacy, Use of ICT in Pedagogy.

\section{Introduction}

The information and communication technology (ICT) plays a vital role in many areas including economics, management, and education. In the educational context, many institutions have applied ICT for teaching and learning in the classroom. Alessi et al. [5], revealed that ICT-based learning provides many advantages such as efficiency in time, wider accessibility in the subject material, and affordability in achieving information [54]. In acquaintance with technological education, (TPACK) technology, pedagogy, and content knowledge provides a creative solution developed in learning [6]. TPACK is knowledge about how to facilitate student learning from certain content through pedagogical and technological approaches [8],[9],[10]. It is considered as a 
potential framework that can provide new directions for teachers in solving problems related to integrating ICT into teaching and learning activities in the classroom [11].

Wong and $\mathrm{Li}$ [12], argued that the implementation of ICT in learning has a significant effect on the development of teacher pedagogical competencies. Furthermore, it found that the implementation of ICT helps change their pedagogical competencies. Precisely, it allows teacher's pedagogical competence in enhancing experiences, classroom conditions, and school cultures. Sara and Ronald [13] also suggested that to implement ICT, teachers should have excellent pedagogical competence first in a supportive climate. However, in both studies equally, explain the existence of a significant influence on the implementation of ICT on learning and student achievement. In contrast to the two studies, [4] stated that there was no substantial evidence that the implementation of ICT could help changes in the students learning and achievement.

Teacher competence also has an impact on the learning process of students. Therefore, it is necessary for teachers who have abilities in their professional fields related to knowledge, attitudes and professional skills aspect [53]. To support the achievement of better learning quality, organizational innovative climate encourages innovative behavior through the development of formal actions and the provision of resources. Generally, organizational innovative climate measures organizational operations, teamwork, learning and growth, leadership success, work approach, environment, organizational values, resources and so forth [14],[15],[16],[17],[18],[19].

Amabile [20],[21] argued that the social circumstance plays an essential role in stimulating individual work motivation. When a person integrates well into an organization, he/she has access to adequate resources, has encouragement and support from the leadership, increasing individual creativity. The seriousness of the teacher in influencing student achievement is referring to the construct of teacher efficacy [22]. The teacher takes into consideration self-effort in influencing students' learning outcomes. Teacher efficacy is known to have a significant relationship with student achievement [23],[24],[25],[26],[27],[28],[29].

Efficacy has to do with the confidence of the individual that influences their behavior towards the situation. This belief includes someone having an effort to take the necessary action of individual consideration of self-efforts in carrying out teaching tasks that encourage the achievement of expected goals. Gibson and Dembo [26] showed that teachers with low efficacy lack seriousness in correcting student weaknesses, also, to tend to judge students based on intelligence and only provide excellent service to intelligent students [24].

Teachers with low efficacy levels also tend to apply disciplinary control by applying penalties to ensure students following the teaching [30]. Meanwhile, when teachers with high efficacy apply mastery experience, strategies versus teachers with low teaching efficacy tend to neglect cognitive development and student effort [26]. High efficacy confidence encourages teachers to put more effort into their teaching assignments with various teaching activities and not give up easily [29]. This study seeks to complement the gaps of previous research by testing the effect of Technological Pedagogical Content Knowledge on the use of ICT in pedagogy. 


\section{$2 \quad$ Literature Review}

\subsection{Overview of Technological Pedagogical Content Knowledge (TPACK)}

Pedagogical Content Knowledge Technology (TPACK) is introduced into the field of educational research as a theoretical framework for understanding teacher knowledge needed to integrate with effective technology [9]. The TPACK framework is built on Shulman's construction of pedagogical content knowledge (PCK) technology knowledge as it lies in pedagogical content and knowledge. The framework in Figure 1 focuses on designing and evaluating teacher knowledge that concentrates on active student learning in various content fields [32]. As such, TPACK is a framework for thinking about what knowledge a teacher must have to integrate technology into teaching and how they develop this knowledge.

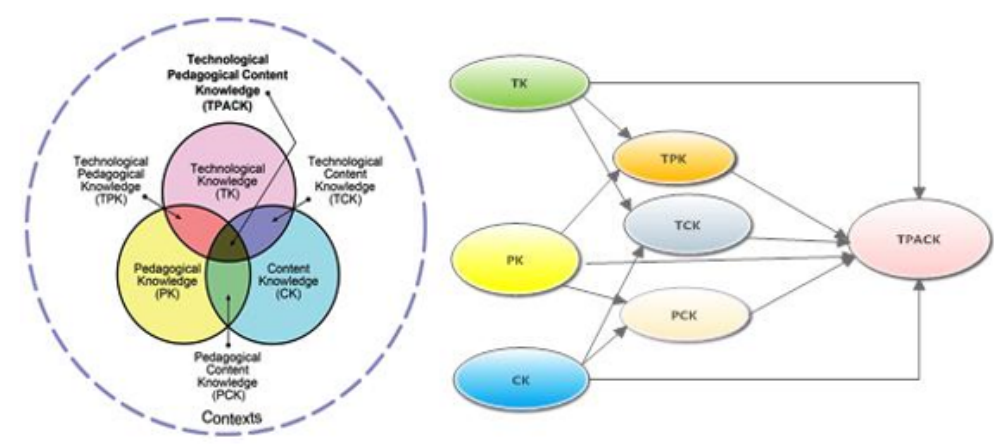

Fig. 1. The TPACK component and extract the structural model of the mutual relationship between TPACK constructs

There are seven variables that affect TPACK [8],[9],[10], including:

- Technological Knowledge (TK) is knowledge of how to operate computers and relevant software

- Pedagogical Knowledge (PK) is the ability in managing student learning

- Content Knowledge (CK) is subject matter of knowledge such as knowledge about language, Mathematics, Natural Sciences, and so forth

- Technological Content Knowledge (TCK) is knowledge about how content can researcher or represent by technology such as using computer simulations to represent and study the movements of the earth's crust

- Pedagogical Content Knowledge (PCK) is knowledge about how to represent and formulate subjects that make them understood by others [10]

- Technological Pedagogical Knowledge (TPK) is knowledge about how technology can facilitate pedagogical approaches such as using asynchronous discussion forums to support the social construction of knowledge 
- Technological Pedagogical Content Knowledge (TPACK) is knowledge about how to facilitate student learning of specific content through pedagogic and technological approaches.

\subsection{Organizational Innovative Climate (OIC)}

Organizational Innovative Climate (OIC) is an organizational atmosphere that encourages innovative behavior through the development of formal actions and tools and the provision of resources. In general, OIC measures organizational operations, teamwork, learning and growth, leadership success, work approaches, environment, organizational values, resources, and so on [33],[15], [16],[17],[18], [19].

For teachers, job autonomy means that their work must be accepted and independently determined by the teacher to develop creative and behavior $[16],[34],[35],[36]$. Teacher job autonomy aims to produce teacher self-growth and emphasizes the need for organizational openness, trust, communication, and participation [37],[38]. For schools, innovative leadership is a crucial factor in sustainable operations. Several previous studies [39],[16],[40] [41],[42] suggested the importance of innovative leadership that goes from closed systems to open network systems.

Bouckenooghe et al. [43] summarized ten dimensions of organizational change from the literature and suggested that trust in leadership, politics, and cohesiveness are essential variables for organizational climate change that members perceive. Amabile [20],[21] argued that the social environment plays an essential role in stimulating individual work motivation.

\subsection{Teachers' Self Efficacy (TSE)}

Self-efficacy has a significant impact on teacher's motivation and personal achievement. According to Gorozidis and Papaioannou [44], teachers with low selfefficacy seem to have lower self-esteem and pessimistic thoughts about their ability to complete tasks. Thus, the level of teachers' self-efficacy can lead to their motivation. It is important to be noted that self-efficacy builds motivation based on perceptions of self-competence rather than the actual level of competence [28]. Bandura [25] argued that a teacher who considers a task difficult then they will be slow in completing the task. This implies that teachers' self-efficacy can have a more significant impact on how successfully a teacher implements instructional strategies, classroom management, and student engagement.

\subsection{Use of ICT in Pedagogy (UIP)}

The use of ICT in Pedagogy (UIP) is learning that uses ICT to transform the learning process between educators and students. The primary purpose of using ICT is to improve efficiency and effectiveness, transparency, and accountability in learning. There are some indicators to measures UIP including: 
- Substitution of ICTs

- Augmentation of ICTs

- Modification of ICTs

- Redefinition of ICTs

These four indicators are known as the SAMR Model. The SAMR Model predicts that when faced with new technology, adaptation will begin with substitution [47]. This adaptation initially involves searching for different applications that use as pedagogical tools. Examples begin with tasks that feel safe, such as adapting existing material so students can access it via iPad. The application found substitution in Microsoft Office suite: pages for word, numbers for excel, and Keynote for Powerpoint. The teacher can also develop lessons that involve the use of various applications and then head to the training session to show how the iPad can be used in the classroom to teach others how to use the various applications.

\section{Method}

\subsection{Research design}

This study applied a quantitative method following a descriptive explanatory approach [49]. There are four main variables in this study include technological pedagogical content knowledge (TPACK), organizational innovative climate (OIC), teachers' self-efficacy (TSE), dan use of ICT in Pedagogy (UIP). The population of this study was approximately 1332 teachers in the Islamic Junior High School in Mojokerto East Java while the sample was about 308 teachers gathered using proportionate stratified random sampling technique. The determinant of the sample follows Slovin's formula [49],[50]. In this study, researchers adopted forty-five indicators developed by [49],[50] to measure UIP and adapted twenty-six indicators from [51], to measure TPACK. Furthermore, this study also adapted sixteen indicators from [41],[42] to measure OIC, and twenty-four indicators from [28], to measure TSE. To collect data, five-point Likert's scale that was applied for each variable from 1 for extremely disagree to 5 for entirely agree. Furthermore, Structural Equation Modeling (SEM) method was apllied to understand the relationship between variables.

Furthermore, the framework of the study is presented in the Figure 2.

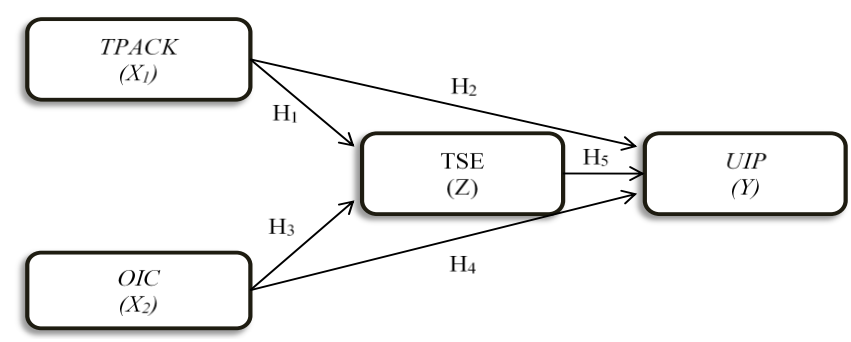

Fig. 2. The Conceptual Framework 


\section{$4 \quad$ Results}

\subsection{Process of data analysis and testing of research models}

This study uses SEM for hypothesis testing. The theoretical model in research (figure 1) has several indicators to test for a causal relationship. This study follows the covariant matrix input for estimation. The test will be carried out using a confirmatory factor analysis model. Model compatibility (goodness of fit) for the analytical confirmation factor will also be tested. With the AMOS program, measures of goodness of fit will appear in its output.

Analysis of confirmatory factors in exogenous constructions: Based on the results of the confirmatory factor analysis conducted on exogenous variables, it is known that the model has fulfilled the goodness of fit criteria set. The goodness of fit test value with $\chi^{2}$ shows equal to 54.307 with a probability $(\mathrm{P})$ of 0.053 indicating absence of the difference between the predicted model and observational data. Measurements the feasibility of the other models is in a suitable category. Furthermore, the results of confirmatory factor analysis on exogenous variables show that each indicator or dimension makes up each latent variable shows a high significance, namely the CR value is far above 1.96 with $\mathrm{P}<0.05$. Based on the confirmatory factor analysis, the research model for exogenous variables used for further analysis.

Analysis of endogenous constructive confirmatory factors: Based on the calculation result of the chi-square test on endogenous constructs obtained a value of 13.162 chi-square dam probability value of 0.155 which value mentioned above 0.05 , besides, other criteria are also met (fit). These results indicate that endogenous constructs meet goodness-of-fit indices. Furthermore, based on the results of the confirmatory factor analysis CR values $>1.96$ above 2.00 with $\mathrm{P}<0.05$. That is, the indicators forming latent variables are indicators or dimensions that are good as a measurement tool.

Structural equation model analysis: Testing the model in SEM is carried out with two tests, namely the model fit test and the significance test of causality through the regression coefficient test. Modifications made by reducing the PK, TCK, RS, and AI indicators. Also, modifications were made by connecting line in one of the possible TPACK errors. This stage has done because the AMOS program recommends variating e1 and e3 errors. 


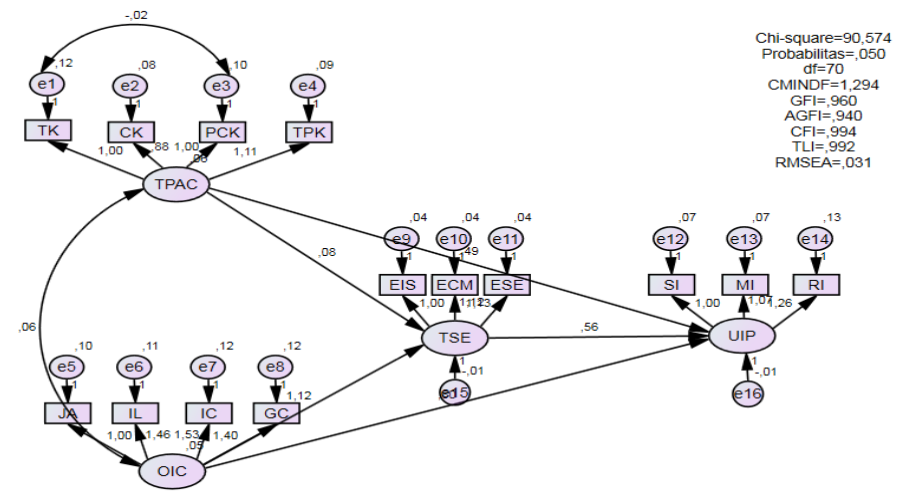

Fig. 3. The Result of Structural Equation Model

Based on the results of the chi-square test on the full model (figure 4) it is known that the chi-square value of 90.574 at a significant level of 5 percent with a value of $P$ $=0.050$. These results indicate that the overall model meets the model fit criteria. The probability value of $\mathrm{P}=0.050$ is included in the cut of value greater than 0.05 as well as other criteria which all meet appropriately. Furthermore, based on the results of SEM analysis regressions, it is known that each indicator forming latent variables shows results that meet the criteria of a $\mathrm{CR}$ value $>1.96$ with $\mathrm{P}<0.05$ and a loading factor value $>0.5$.

\subsection{Analysis of problem identification}

Multivariate outliers evaluation testing is conducted by analyzing d-squared Mahalanobis. The test results of this study indicate that the minimum distance of Mahalanobis is 16.339 and a maximum of 41.496 . Based on the chi-square value at 120 degrees free at a significance level of 0.05 or $\chi^{2}=90.53$, it indicates that there is no multivariate outlier. Next is an evaluation of multicollinearity and singularity. The output of the determination of the SEM-AMOS covariance matrix determinant sample program is the determinant of the sample covariance matrix $=0.000$. From the output of the determinant calculation results of the sample covariance matrix, the determinant of sample covariance matrix values can be found to be near 0 .

Test the suitability of the research model used to test how good the level of goodness of fit of the research model. Based on the results of our model tests we get a value of $\mathrm{P}$ $=0.05(\mathrm{P} \geq 0.05), \mathrm{Cmin} / \mathrm{df}=1.294<2.00, \mathrm{RMSEA}=0.031<0.08 \mathrm{GFI}$ value $=0.960$ $>$ cut off value 0.90 , AGFI value $=0.940>$ cut off 0.90 , TLI $=0.992>0.95$, and the value of $\mathrm{CFI}=0.960>0.95$. Furthermore, a good model has a small Standardized Residual Covariance. Number +2.58 is the limit of standardized residual values allowed. Based on the results of the statistical analysis, it found that there is no standardized residual covariance value of more than 2.58. It implies that the residual requirement is fulfilled. 


\subsection{Research hypothesis testing}

Table 1. Research Hypothesis Testing

\begin{tabular}{|l|c|c|c|c|c|}
\hline & Estimate & S.E & C.R & P & $\begin{array}{c}\text { P-Value } \\
\text { Sobel Test }\end{array}$ \\
\hline Direct Influence: & & & & & \\
\hline TPACK $\rightarrow$ TSE & 0.080 & 0.133 & 0.603 & 0.546 & \\
\hline TPACK $\rightarrow$ UIP & 0.489 & 0.132 & 3.710 & $* * *$ & \\
\hline OIC TSE $\rightarrow$ UIP & 1.117 & 0.163 & 6.840 & $* * *$ & \\
\hline OIC $\rightarrow$ UIP & 0.800 & 0.335 & 2.386 & 0.017 & \\
\hline TSE & 0.559 & 0.200 & 2.795 & 0.005 & \\
\hline Indirect Influence: & & & & & \\
\hline TPACK $\rightarrow$ TSE $\rightarrow$ UIP & & & & & 0.55650 \\
\hline OIC $\rightarrow$ TSE $\rightarrow$ UIP & & & & & 0.00965 \\
\hline
\end{tabular}

The first hypothesis of this study, TPACK has a positive effect on TSE. Based on table 2, it is known that the value of $\mathrm{CR}=0.603$ and the value of $\mathrm{P}=0.546$. Table 2 also shows the value of $\mathrm{CR}<1.978$ and the value of $\mathrm{P}>0.05$. Thus, it can be said that the first hypothesis of this study rejected. Statistically, the Technological Pedagogical Content Knowledge (TPACK) does not affect the Teachers' Self Efficacy (TSE).

The second hypothesis of this study, TPACK, has a positive effect on Use UIP. The results of testing the value of $\mathrm{CR}=3.710$ and the value of $\mathrm{P}=0.000$. With the second hypothesis, this study accepted. That is, TPACK affects UIP. The third hypothesis of this study is that OIC has a positive effect on TSE. The test results show the value of $\mathrm{CR}=6.840$ and the value of $\mathrm{P}=0.000$. Thus the third hypothesis is accepted, meaning that OIC influences TSE.

The fourth hypothesis of this study OIC has a positive effect on UIP. The test results show the value of $\mathrm{CR}=2.386$ and $\mathrm{P}=0.017$. Furthermore, the fourth hypothesis is accepted; there is an influence of OIC on UIP. The fifth hypothesis of this study TSE has a positive effect on UIP. The test results show the value of $\mathrm{CR}=2.795$ and $\mathrm{P}=$ 0.005. Thus, the fifth hypothesis is accepted, meaning that TSE affects the UIP. The sixth hypothesis states that TPACK has an indirect effect through the TSE on UIP. The test results show the value of $\mathrm{P}$ on the Sobel Test $=0.55650>0.05$. Thus the sixth hypothesis is rejected, meaning that TPCK has no direct effect on UIP mediated by TSE. The seventh hypothesis of OIC has an indirect effect on UIP mediated by TSE. The result of the P-value test is Sobel Test $=0.00965<0.05$. Thus hypothesis seven can be accepted, meaning that OIC has an indirect effect on UIP mediated by TSE.

\section{Discussions}

Based on the previous test, it is known that first, TPACK did not affect TSE. It means that respondents do not think that the teacher's belief can produce positive students in relation to their technology, pedagogy, and content of knowledge material. In addition, their moderate ability in terms of TPACK has nothing to do with their self-efficacy, and their self-efficacy which does not result in their ability being also in TPACK. This 
finding supports the previous study by [3] which mentioned that there is no relationship between variables. However, the result of the study in opposite with studies by [2] which remarked a correlation between variables. It implies that the higher of TPACK will probably not affect teachers' self-efficacy.

On the other hand, from the statistical results, it can be drawn that TPACK significantly affects UIP. This finding shows results that are in line with [1] which stated that the majority of respondents have low pedagogical ICT competence. Teachers have a good level of knowledge in all TPACK and SAMR constructs that score, prospective teachers have low skills and inefficient support in the use of basic ICT. The impact of TPACK and the characteristics of the SAMR model associated with planning the use of technology and redesign of learning tasks are evident. Most of the challenges identified were related to lack of infrastructure, readiness to change and lack of competence in pedagogical ICT applications. Similarly, a prior study by [9] mentioned that with TPACK being better than these teachers, UIP will be better too. The use of Skype is also limited to the time and conditions in the sense that teachers and students do not always have the same free time and also not all regions are covered by good signals that make it difficult to connect with Skype for example.

Furthermore, the results of testing the effect of OIC on the TSE showed a significant correlation. Similarly, the findings of this study support the prior studies by [41],[42]. The results of the work in the field also indicate that there are schools and teachers who are not involved in the planning, creation and even implementation of these innovations. As a result, the new idea or innovation is considered by the teacher or schools not their and belongs to someone else who does not need to be implemented because it is not following the wishes or conditions of their school.

Organizational innovative climate also influences the use of ICT in pedagogy. The results of this study are in line with the findings of [14],[15] which mentioned a positive correlation between variables. On the other hand, it means that a better organizational innovative climate will lead to greater the use of ICT in pedagogy. Meanwhile, based on the test, it is known that teachers' self-efficacy influences the use of ICT in pedagogy. The results of this study support by [28] findings that teachers' self-efficacy directly has a positive and significant influence on the use of ICT in pedagogy. For students' closed behavior, the stimulus is needed in the form of attention, perception, knowledge or awareness.

The test results of the study show that the indirect effect of between organizational innovative climate on the use of ICT in pedagogy through teachers' self-efficacy. This finding in contract with previous research by [53] which mentioned that TPACK significantly influences TSE and perceived ease to use technology. TPACK is also positively influenced by perceived ease to use technology and perceived usefullness technology in the classroom. Finally, TSE, perceived ease to use and perceived usefulness using technology have an effect on Intention to use technology. TPACK does not directly affect the intention to use technology.

The conclusion is that TPACK through Teachers' self-efficacy on the use of ICT in Pedagogy does not directly have a positive and significant effect. Therefore, the higher the TPACK and TSE the teacher has, the TSE will not necessarily increase. In this study, TSE cannot be used as an intervening variable but TSE can only be an 
independent variable. Lastly, the results of testing showed that the indirect effect of organizational innovative climate through teachers' self efficacy on the use of ICT in Pedagogy is significant. This finding agrees a previous study by [55] which remarked that the continuous use of e-teaching between teachers is positive and significant. Organizational innovative climate for continuous use of e-teaching directly and indirectly through computer self-efficacy. The conclusion is that organizational innovative climate through the teachers' self-efficacy on the use of ICT in Pedagogy directly has a positive and significant effect. Therefore, the higher the OIC and TSE the teacher has, the UIP will definitely increase. In this study, TSE can be used as an intervening variable.

\section{Conclusion}

This study examines the effect of technological pedagogical content knowledge on the use of ICT in pedagogy. The results showed that: first, technological pedagogical content knowledge directly did not affect teachers' self-efficacy but it significantly influences the use of ICT in pedagogy. Further, an innovative organizational climate directly influences the teachers' self-efficacy and the use of ICT in pedagogy. In addition, teachers' self-efficacy affects the use of ICT in pedagogy. Sixth, technological pedagogical content knowledge mediated by teachers' self-efficacy does not directly affect the use of ICT in pedagogy while organizational innovative climate-mediated by teachers' self-efficacy affects the use of ICT in pedagogy. Based on the findings it is provided some suggestions that technological pedagogical content knowledge should be improved. Furthermore, the innovative organizational climate must be enhanced by creating an organizational atmosphere that encourages innovative behavior through the development of formal actions and tools, as well as the provision of resources. This study is the first step for a similar study in the future. Further researchers are suggested to expand the scope of research and with a higher number of respondents and not only in the scope of the school, but also can be conducted at schools under the auspices of the Ministry of National Education.

\section{$7 \quad$ References}

[1] Kihoza, P., Zlotnikova, I., Bada, J., \& Kalegele, K. (2016). Classroom ICT integration in Tanzania: Opportunities and challenges from the perspectives of TPACK and SAMR models. International Journal of Education and Development Using Information and Communication Technology, 12(1), 107-128.

[2] Rohann, E., Takonis, R., \& Jochems, W. (2012). Analyzing teacher knowledge for technology education in primary schools. International Journal of Technology and Design Education, 22(3), 271-280. https://doi.org/10.1007/s10798-010-9147-z

[3] Gonzales, A. L. (2018). Exploring Technological, Pedagogical, and Content Knowledge (TPACK) and Self Efficacy Belief of Senior High School Biology Teachers in Batangas City. Palawan Scientist, 10, 29-47. 
[4] Sangrà, A., \& González-Sanmamed, M. (2010) The role of information and communication technologies in improving teaching and learning processes in primary and secondary schools. ALT-J, 18(3), 207-220, https://doi.org/10.1080/09687769.2010.529108

[5] Alessi \& Trollip. (2001). Multimedia for learning: Methods and development. Massachusetts: A Pearson Education.

[6] Sutrisno. (2012). Kreatif Mengembangkan Aktivitas Pembelajaran Berbasis TIK. Jakarta: Gaung Persada.

[7] Shulman, L. S. (1986). Those who understand: knowledge growth in teaching. Educational Researcher, 15(2), 4-14. https://doi.org/10.3102/0013189x015002004

[8] Angeli, C., \& Valanides, N. (2009). Epistemological and methodological issues for the conceptualization, development, and assessment of ICT-TPACK: advances in technological pedagogical content knowledge (TPACK). Computers \& Education, 52(1), 154-168. https://doi.org/10.1016/j.compedu.2008.07.006

[9] Mishra, P., \& Koehler, M. J. (2006). Technological pedagogical content knowledge: a framework for teacher knowledge. Teachers College Record, 108(6), 1017-1054. https:// doi.org/10.1111/j.1467-9620.2006.00684.x

[10] Cox, S., \& Graham, C. R. (2009). Diagramming TPACK in practice: using and elaborated model of the TPACK framework to analyze and depict teacher knowledge. TechTrends, 53(5), 60-69. https://doi.org/10.1007/s11528-009-0327-1

[11] Hewitt, J. (2008). Reviewing the handbook of technological pedagogical content knowledge (TPCK) for educators. Canadian Journal of Science, Mathematics, and Technology Education, 8(4), 355-360. https://doi.org/10.1080/14926150802506274

[12] Wong, Emily \& Li, Sandy. (2008). Framing ICT Implementation in a Context of Educational Change: A Multilevel Analysis. School Effectiveness and School Improvement. 19. 99-120. https://doi.org/10.1080/09243450801896809.

[13] Dexter, S., Anderson, R. E., \& Becker, H. J. (1999). Teachers' views of computers as catalysts for changes in their teaching practice. Journal of Research on Computing in Education, 31 (3), 221-239. https://doi.org/10.1080/08886504.1999.10782252

[14] Chen, C. J., \& Huang, J. W. (2007). How organizational climate and structure affect knowledge management-The social interaction perspective. International journal of information management, 27 (2), 104-118. https://doi.org/10.1016/j.ijinfomgt.2006.11.001

[15] Chiu, Chao-Min \& Lin, Hua-Yang \& Sun, Szu-Yuan \& Hsu, Meng-Hsiang. (2009). Understanding customers' loyalty intentions towards online shopping: An integration of technology acceptance model and fairness theory. Behaviour \& IT. 28. 347-360. https:// doi.org/10.1080/01449290801892492.

[16] Gumusluoglu, L., \& Ilsev, A. (2009). Transformational leadership, creativity, and organizational innovation. Journal of business research, 62(4), 461-473. https://doi. org/10.1016/j.jbusres.2007.07.032

[17] King, E. B., De Chermont, K., West, M., Dawson, J. F., \& Hebl, M. R. (2007). How innovation can alleviate negative consequences of demanding work contexts: The influence of climate for innovation on organizational outcomes. Journal of Occupational and Organizational Psychology, 80(4), 631-645. https://doi.org/10.1348/096317906x $\underline{171145}$

[18] Patterson, M. G., West, M. A., Shackleton, V. J., Dawson, J. F., Lawthom, R., Maitlis, S., $\&$ Wallace, A. M. (2005). Validating the organizational climate measure: links to managerial practices, productivity and innovation. Journal of organizational behavior, 26(4), 379-408. https://doi.org/10.1002/job.312 
[19] Shieh, C. J. (2010). Supply chain management, organizational innovation and corporate culture: The impact of relatedness. African Journal of Business Management, 4(9), 17361744.

[20] Amabile, T.M. (1983). The social psychology of creativity. New York: Springer-Verlag.

[21] Amabile, T.M. (1996). Creativity in context. Westview Press: Boulder

[22] Bandura, A. (1997). Self-efficacy: The exercise of control. New York: W. H. Freeman and Company.

[23] Anderson, R., Greene, M., \& Loewen, P. (1988). Relationships among teachers' and students' thinking skills, sense of efficacy, and student achievement. Alberta Journal of Educational Research, 34(2), 148-165.

[24] Ashton, P. T., Webb, R.B. \& Doda, N. (1983). A study of teacher's sense of efficacy. Final Report to the National Institute of Education, Executive Summary. Gainesville: University of Florida.

[25] Bandura, A. (1993). Perceived self-efficacy in cognitive development and functioning. Educational Psychologist, 28(2),117-148. https://doi.org/10.1207/s15326985ep2802_3

[26] Gibson, S., \& Dembo, M. H. (1984). Teacher efficacy: A construct validation. Journal of educational psychology, 76(4), 569-582. https://doi.org/10.1037//0022-0663.76.4.569

[27] Ross, J. A. (1992). Teacher efficacy and the effect of coaching on student achievement. Canadian Journal of Education, 17(1), 51-65.

[28] Tschannen-Moran, M. and Woolfolk Hoy, A. (2001). Teacher efficacy: Capturing an elusive construct. Teaching and Teacher Education, 17, pp.783 - 805. https://doi.org/10. 1016/s0742-051x(01)00036-1

[29] Tschannen-Moran, M., Woolfolk Hoy, A., \& Hoy, W. K. (1998). Teacher efficacy: Its meaning and measure. Review of Educational Research, 68, 202-248. https://doi.org/10. $\underline{3102 / 00346543068002202}$

[30] Woolfolk, A.E. \& Hoy, W.K. 1990. Prospective teachers' sense of efficacy and beliefs about control. Journal of Educational Psychology 82: 81-91. https://doi.org/10.1037// 0022-0663.82.1.81

[31] Thompson, A., \& Mishra, P. (Winter 2007-2008). Breaking news: TPCK becomes TPACK! Journal of Computing in Teacher Education, 24 (2).

[32] AACTE Committee on Innovation and Technology (Ed.). (2008). Handbook of technological pedagogical content knowledge (TPCK) for educators. New York: Routledge.

[33] Chen, C. J., \& Huang, J. W. (2007). How organizational climate and structure affect knowledge management-The social interaction perspective. International journal of information management, 27(2), 104-118. https://doi.org/10.1016/j.ijinfomgt.2006.11.001

[34] Reuvers, M., van Engen, M. L., Vinkenburg, C. J. \& Wilson-Evered, E. (2008). Transformational Leadership and Innovative Work Behavior: Exploring the Relevance of Gender Differences. Leadership and Innovation, 17(3), 227-244. https://doi.org/10.1111/j. 1467-8691.2008.00487.x

[35] Rooney, J. A., \& Gottlieb, B. H. (2007). Development and initial validation of a measure of supportive and unsupportive managerial behaviors. Journal of Vocational Behavior, 71(2), 186-203. https://doi.org/10.1016/j.jvb.2007.03.006

[36] Tsai, M. C., Cheng, C. C., \& Chang, Y. Y. (2010). Drivers of hospitality industry employees job satisfaction, organizational commitment and job performance. African Journal of Business Management, 4(18), 4118-4134.

[37] Panaccio, A., \& Vandenberghe, C. (2009). Perceived organizational support, organizational commitment and psychological well-being: A longitudinal study. Journal of Vocational Behavior, 75(2), 224-236. https://doi.org/10.1016/j.jvb.2009.06.002 
[38] Yang, Y. C., \& Hsu, J. M. (2010). Organizational process alignment, culture and innovation. African Journal of Business Management, 4(11), 2231-2240.

[39] Dunn, S., \& Mott, C. (2009). Building a climate for innovation. Business Intelligence, Aprill, $52-54$.

[40] Harryson, S. J. (2008). Entrepreneurship through relationships-navigating from creativity to commercialisation. R\&d Management, 38(3), 290-310. https://doi.org/10.1111/j.14679310.2008.00516.x

[41] Khaliq, M. J., Zia-ur-Rehman, M., \& Rashid, M. (2011). The role of human resource management and nurses job satisfaction in medical service organisations. African Journal of Business Management, 5(3), 974-986.

[42] Wang, F. J., Chich-Jen, S., \& Mei-Ling, T. (2010). Effect of leadership style on organizational performance as viewed from human resource management strategy. African Journal of Business Management, 4(18), 3924-3936.

[43] Bouckenooghe, D., Devos, G., \& Van den Broeck, H. (2009). Organizational change questionnaire-climate of change, processes, and readiness: Development of a new instrument. The Journal of psychology, 143(6), 559-599. https://doi.org/10.1080/00223 $\underline{980903218216}$

[44] Gorozidis, Georgios \& Papaioannou, Athanasios. (2013). Teachers' motivation to participate in training and to implement innovations. Teaching and Teacher Education. 39. 1-11. https://doi.org/10.1016/j.tate.2013.12.001

[45] Bandura, A. (Ed.). (1995). Self-efficacy in changing societies. New York, NY, US: Cambridge University Press.

[46] Puentedura, R. (2006). Transformatiom, Technology, and Education. Presentation given August 18, 2006 as part of the Strengthening Your District Through Technology workshops, Maine, US.

[47] Bandura, A. (1995). Self-efficacy in changing societies. New York: Cambridge University Press.

[48] Puentedura, R. (2006). Transformatiom, Technology, and Education. Presentation given August 18, 2006 as part of the Strengthening Your District Through Technology workshops, Maine, US. Retrieved from http://hippasus.com/resources/tte/part1.html.

[49] Batiibwe, M. S., Bakkabulindi, F. E., \& Mango, J. M. (2016). Application of the Technological, Pedagogical, and Content Knowledge Framework in a Positivist Study on the Use of ICT in Pedagogy by Teachers of Mathematical Disciplines at Makerere University: A Conceptual Paper. Makerere Journal of Higher Education, 8(2), 115-127. https://doi.org/10.4314/majohe.v8i2.3

[50] Jude, L. T., Kajura, M. A., \& Birevu, M. P. (2014). Adoption of the SAMR model to asses ICT pedagogical adoption: A case of Makerere University. International Journal of eEducation, e-Business, e-Management and e-Learning, 4(2), 106. https://doi.org/10.7763/ ijeeee.2014.v4.312

[51] Chai, C. S., Koh, J. H. L., Tsai, C. C., \& Tan, L. L. W. (2011). Modeling primary school pre-service teachers' Technological Pedagogical Content Knowledge (TPACK) for meaningful learning with information and communication technology (ICT). Computers \& Education, 57(1), 1184-1193. https://doi.org/10.1016/j.compedu.2011.01.007

[52] Joo, Y. J., Park, S., \& Lim, E. (2018). Factors influencing preservice teachers' intention to use technology: TPACK, Teacher Self-efficacy, and Technology Acceptance Model. Journal of Educational Technology \& Society, 21(3), 48-59.

[53] Papadakis, S. (2018). Evaluating pre-service teachers' acceptance of mobile devices with regards to their age and gender: a case study in Greece.IJMLO, 12(4), 336-352. https:// doi.org/10.1504/ijmlo.2018.095130 
[54] Kalogiannakis, M., \& Papadakis, S. (2019). Evaluating pre-service kindergarten teachers' intention to adopt and use tablets into teaching practice for natural sciences. International Journal of Mobile Learning and Organisation, 13(1), 113-127. https://doi.org/10.1504/ ijmlo.2019.10016617

[55] Moeinikia, M., Zahed-Babelan, A., Seyyedkalan, S., \& Karimianpur, G. (2016). Investigating the Effect of Organizational Innovative Climate on Continuous Use of Electronic Teaching with the Role of Computer Self-Efficacy Among Male Teachers. Interdiscip J Virtual Learn Med Sci, 7(4), 1-11. https://doi.org/10.5812/ijvlms.10170

\section{Authors}

Hanna Andyani is a doctorate student of University Negeri Malang, Malang, Indonesia.

Punaji Setyosari is a profesor in the post Graduate program of the Department of Education and Technology, Universitas Negeri Malang, Malang, Indonesia.

Bambang Budi Wiyono a profesor in the post Graduate program of the Department of Education and Technology, Universitas Negeri Malang, Malang, Indonesia.

Ery Tri Djatmika a profesor in the post Graduate program of the Department of Manajemen, Universitas Negeri Malang, Malang, Indonesia.

Article submitted 2019-09-18. Resubmitted 2019-12-05. Final acceptance 2019-12-05. Final version published as submitted by the authors. 